\title{
Reducing Deaths by Diet: A Call for Public Policy to Prevent Chronic Disease
}

Norm Campbell CM, MD, FRCPC, Michel Sauvé MD FRCP FACP FCCP MSc

\begin{abstract}
About the Authors
Norm Campbell CM MD FRCPC is with the Division of General Medicine, Community Health Sciences and Physiology and Pharmacology and is a member of the O'Brien Institute of Public Health and Libin Cardiovascular Institute of Alberta at the University of Calgary in Alberta. Michael Sauve is with the Northern Lights Regional Health Centre in Fort McMurray, Alberta.

Correspondence may be directed toncampbel@ucalgary.ca.
\end{abstract}

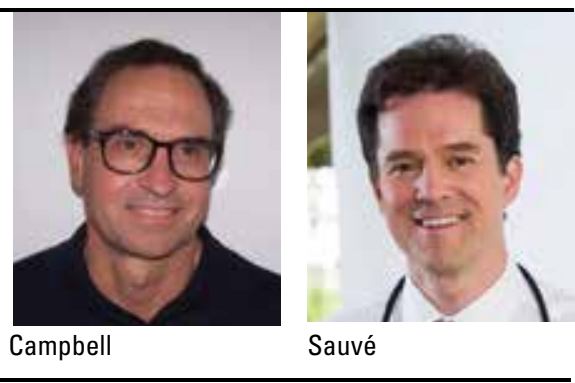

\section{Introduction}

Chronic diseases including cardiovascular disease and cancer are the leading causes of disability and death in Canada. ${ }^{1,2}$ The majority of chronic diseases are caused by physical inactivity, tobacco use, excess alcohol consumption and unhealthy diet. ${ }^{3-6}$ In particular, unhealthy diet is the leading risk factor for death and disability in Canada resulting in an estimated 64,000 deaths and over 1 million years of disability (DALYs) in 2010 alone. ${ }^{7}$ Worldwide, a staggering 11 million deaths and over 200 million DALYs were attributed to unhealthy eating in 2010 .

The usual Canadian diet is unhealthy, high in saturated fat, trans-fats, free sugars, and salt and low in fresh fruit, whole-grains, and vegetables (including legumes /beans)..$^{8-12}$ An estimated 30,000 deaths could be delayed annually if our diets complied with Canadian dietary recommendations, particularly for fruit, and vegetable intake. ${ }^{13}$ In fact, the estimated risk of cardiovascular disease is reduced by about $4 \%$ and total premature death rate reduced by $6-7 \%$ for each additional serving of fruit and vegetable daily. ${ }^{14}$

The World Health Organization (WHO) advocates population approaches to achieve healthy diets as being critical to reduce non-communicable diseases (NCDs). The United Nations has established 9 targets to halt the rise in chronic disease including stopping the increase in obesity, reducing uncontrolled hypertension by $25 \%$ and reducing dietary salt by $30 \%$ by $2025 .{ }^{5}$ Many countries are implementing populationbased policies to reduce dietary risk with success; however, Canadian approaches focus largely on individual behavior change. ${ }^{6}$ In contrast, Canadian governmental and nongovernmental chronic disease strategies strongly recommend population-based interventions to improve diet. ${ }^{17-20}$ However, few effective population-based interventions to improve diet have been implemented to date. While individual behaviour choices are clearly important, it is unlikely that substantive progress will be made without a comprehensive set of population-based interventions to facilitate healthy choices being feasible and easy for individuals to make. ${ }^{16}$

\section{Introduction}

Les maladies chroniques, dont les affections cardiovasculaires et le cancer, sont les principales causes d'incapacité et de mortalité au Canada ${ }^{1,2}$. La plupart des maladies chroniques résultent de l'inactivité physique, de l'usage du tabac, de la consommation excessive d'alcool ou d'une mauvaise alimentation ${ }^{3-6}$. Plus particulièrement, en 2010 seulement, la mauvaise alimentation a été le principal facteur de risque de mortalité et d'incapacité au Canada, en causant environ 64000 décès et plus d'un million d'années de vie ajustée en fonction de l'incapacité (AVAI) ${ }^{7}$. À l'échelle mondiale, toujours en 2010, on attribue les nombres ahurissants de 11 millions de décès et de plus de 200 millions d'AVAI en raison de la mauvaise alimentation.

Le régime alimentaire canadien courant s'avère malsain, riche en gras saturés, en gras trans, en sucre libres et en sel, en plus d'être pauvre en fruit frais, en grains entiers et en légumes (incluant les légumineuses) ${ }^{8-12}$. Environ 30000 vies pourraient être prolongées annuellement si notre alimentation respectait les recommandations du Guide alimentaire canadien, notamment en matière de consommation de fruits et de légumes ${ }^{13}$. En fait, on estime que l'ajout quotidien d'une portion de fruits ou de légumes au régime alimentaire fait diminuer le risque de maladie cardiovasculaire d'environ $4 \%$ et le taux de décès prématuré de 6 à $7 \%^{14}$.

L'Organisation mondiale de la santé (OMS) défend l'idée que les méthodes axées sur la population pour instaurer de saines habitudes alimentaires sont essentielles à la réduction $\mathrm{du}$ nombre de cas de maladies non transmissibles. Dans le but de freiner l'augmentation des maladies chroniques, l'Organisation 
des Nations Unies a fixé neuf objectifs à atteindre d'ici 2025, dont l'arrêt de la progression de l'obésité, la réduction de $25 \%$ du nombre de cas d'hypertension non normalisée et une baisse de $30 \%$ de la consommation de $\operatorname{sel}^{5}$. En vue de réduire les risques liés à la mauvaise alimentation, nombre de pays instaurent avec succès des politiques axées sur la population, pendant qu'au Canada les méthodes actuelles se concentrent plutôt sur le changement des comportements individuels ${ }^{6}$. En revanche, les stratégies canadiennes gouvernementales et non gouvernementales relatives aux maladies chroniques recommandent fortement la mise en ouvre de politiques de population pour favoriser une meilleure alimentation ${ }^{17-20}$. Par contre, peu de ces interventions ont été mises en place à ce jour. Il est clair que les choix de comportements individuels sont importants, mais il est peu probable que les choses s'améliorent de façon significative sans l'instauration d'un ensemble de mesures axées sur la population en général et permettant aux individus de faire des choix sains plus facilement ${ }^{16}$.

\section{A National Health Sector Response}

Over 15 Canadian health-related organizations, including the Canadian Society of Internal Medicine, have supported a Call to Action to Implement a Healthy Food Policy Agenda. ${ }^{21}$

Based on international recommendations, the Call advocates key components of a comprehensive food strategy that could meaningfully reduce the diet-related chronic disease including: ${ }^{3,5,6,8,15,21,22}$

- restricting the marketing of foods and beverages to children.

- regulating the additions of sodium, free-sugars, and transfats in processed foods.

- promoting intake of whole grains, fruits and vegetables including legumes/beans.

- promoting the reduction of saturated fats in our diet.

- establishing simple easy-to-understand nutrition labeling on processed food products and in dining establishments

- introducing targeted subsidies for healthy food products combined with taxation of unhealthy food/beverage products.

- implementing healthy food and beverage procurement policies in publicly-funded and private sector settings.

- developing standards to reduce conflicts of interest in nutrition policy development, research and education.

\section{Advocacy Opportunities}

General Internists are important opinion leaders and can play strong advocacy roles. All levels of Canadian government have the authority to impact healthy and unhealthy diets through public policy; however, Canada's health and scientific organizations, the private sector, and individuals all need to play important roles.

To the extent that chronic disease represents the greatest burden of diet-related disease managed in adults by General Internists, we have an important opportunity to advocate at the clinical and public health level. This can start by supporting national calls to action for governments to respond and act. The impact of poor diet on premature morbidity and mortality should be a focus in all internal medicine academic and education-related endeavors, including publications. Likewise, Internists can advocate for more research funding to assess and monitor dietary trends and the impact of nutrition policy on public health outcomes to inform future research and policy priorities.

Canadian policy responses to diet-related death and disability are inadequate and are falling behind those of other countries. Recently five key messages were proposed to be the basis for unified action on obesity. ${ }^{16}$ The messages recognize:

1) that the epidemic of diet-related chronic disease will not be reversed without strong government leadership.

2) the status quo will be costly in terms of population health, health care expenses, and loss of productivity.

3) there is limited impact and low sustainability of education efforts aimed at the individual level.

4) there is a need to accurately monitor and evaluate population nutrition data and intervention outcomes.

5) that a multi-sectoral systems approach is needed.

Canadian policies are lagging behind the global community in response to the increasing burden of chronic disease. The time is now for Canadian General Internists to play a stronger role in reversing this trend. 


\section{References}

1. Advisory Committee on Population Health and Health Security Surveillance Systems for Chronic Disease Risk Factors Task Group. Enhancing capacity for surveillance of chronic disease risk factors and determinants. Ottawa (ON): Chronic Disease Risk Factors Task Group; 2005 Jun.

2. Jacka FN, Mykletun A, Berk M, Bjelland I, Tell GS: The association between habitual diet quality and the common mental disorders in communitydwelling adults: the Hordaland Health study. Psychosom Med 2011, 73:483-490

3. Mozaffarin D, Afshin A, Benowtiz NL et al. Population Approaches to Improve Diet, Physical Activity, and Smoking Habits: A Scientific Statement from the American Heart Association. Circulation. 2012 Sep 18;126(12):1514-63.

4. Beaglehole R, Bonita R, Horton R, Adams C, Alleyne G, Asaria P et al. Priority actions for the non-communicable disease crisis. Lancet 2011; 377(9775):1438-1447. Available at: http://www.thelancet.com/journals/ lancet/article/PIIS0140-6736\%2811\%2960393-0/abstract.

5. World Health Organization. Global Action Plan for the prevention and control of NCD 2013-2020. Available at: http://www.who.int/nmh/en/.

6. Hawkes C, Jewell J, Allen K. A food policy package for healthy diets and the prevention of obesity and diet-related non-communicable diseases: the NOURISHING framework. Obes Rev. 2013 Nov;14 Suppl 2:159-68.

7. Institute for Health Metrics and Evaluation. Global Burden of Disease Arrow Diagram. Seattle, WA: IHME, 2013. Available at: http://www. healthmetricsandevaluation.org/gbd/visualizations/gbd-arrow-diagram (Accessed March 15 2010).

8. World Health Organization. Set of recommendations on the marketing of foods and non-alcoholic beverages to children. World Health Organization, 2010. Available at: http://www.who.int/dietphysicalactivity/publications/ recsmarketing/en/index.html (Accessed September 13, 2013).

9. Alberta Health and Wellness. Alberta Nutrition Guidelines for Adults. Available at: www.healthyalberta.com/NutritionGuidelines-Adults-Aug2012. pdf. Accessed June 7, 2014.

10. Ministry of Health of Brazil. Dietary Guidelines for the Brazilian population. Ministry of Health of Brazil, 2014. Available at: 189.28.128.100/dab/docs/.../ guia_alimentar_populacao_ingles.pdf.

11. Garriguet D. Canadians' eating habits. Health Reports. (Statistics Canada Catalogue 82-003) 2007; 18(2):17-32. Available at: http://www.statcan.gc.ca/ pub/82-003-x/2006004/article/habit/9609-eng.pdf (Accessed July 10 2013).
12. Moubarac JC, Martins AP, Claro RM, Levy RB, Cannon G, Monteiro CA. Consumption of ultra-processed foods and likely impact on human health. Evidence from Canada. Public Health Nutr. 2013 Dec;16(12):2240-8.

13. Bélanger M, Poirier M, Jbilou J, Scarborough P. Modelling the impact of compliance with dietary recommendations on cancer and cardiovascular disease mortality in Canada. Public Health. 2014 Mar;128(3):222-30.

14. Wang X, Ouyang Y, Liu J, Zhu M et al. Fruit and vegetable consumption and mortality from all causes, cardiovascular disease, and cancer:systematic review and dose-response meta-analysis of prospective cohort studies. BMJ. 2014;349:g4490 doi.

15. Vandevijvere S, Swinburn B, and for the International Network for Food and Obesity/non-communicable diseases (NCDs) Research, Monitoring and Action Support (INFORMAS). Towards global benchmarking of food environments and policies to reduce obesity and diet-related noncommunicable diseases: design and methods for nation-wide surveys. BMJ Open. 2014; 4(5): e005339.

16. Urgently needed: a framework convention for obesity control. Lancet. 2011; 378(9793):741.

17. Public Health Agency of Canada. Integrated Pan-Canadian Healthy Living Strategy. Ottawa, ON: Public Health Agency of Canada; 2005. Available at: http://www.phac-aspc.gc.ca/hp-ps/hl-mvs/ipchls-spimmvs/index-eng.php.

18. Public Health Agency of Canada. Curbing childhood obesity: a federal, provincial, and territorial framework for action to promote healthy weights. Ottawa, ON: Public Health Agency of Canada; 2010. Available at: www.phacaspc.gc.ca/hp-ps/hl-mvs/framework-cadre/index-eng.php. Accessed 2014 Sep 16.

19. Sodium Working Group. Sodium Reduction Strategy for Canada. Health Canada, Ottawa, Canada, 2010. Available at: http://www.hc-sc.gc.ca/fn-an/ nutrition/sodium/related-info-connexe/strateg/index-eng.php.

20. Public Health Agency of Canada. Preventing Chronic Disease Strategic Plan 2013-2016. Ottawa, ON: Public Health Agency of Canada; 2013. Available at: http://www.phac-aspc.gc.ca/cd-mc/diabetes-diabete/strategy_plan-plan_ strategique-eng.php.

21. Reedy, J., Krebs-Smith, S. M., Miller, P. E., Liese, A. D., Kahle, L. L., Park, Y., \& Subar, A. F. (2014). Higher diet quality is associated with decreased risk of all-cause, cardiovascular disease, and cancer mortality among older adults. The Journal of Nutrition, 144(6), 881-889. PMCID: PMC4018951.

22. Trumbo, P. R., \& Shimakawa, T. (2011). Tolerable upper intake levels for trans fat, saturated fat, and cholesterol. Nutrition Reviews, 69(5), 270-278. PMID: 21521229. 